\title{
A Quantitative Analysis of Anthropogenic Pollution on Ground Water in Douala
}

\author{
Akenji Victorine $\mathrm{Neh}^{1 *}$ and Tarkang Carine Enow ${ }^{2}$ \\ ${ }^{1}$ Ministry of Scientific Research and Innovation (MINRESI), National Center for Education (CNE), Yaounde, Cameroon \\ ${ }^{2}$ Hydrological Research Centre Yaounde, Yaounde, Cameroon \\ *Corresponding Author: Akenji Victorine Neh, Ministry of Scientific Research and Innovation (MINRESI), National Center for Education \\ (CNE), Yaounde, Cameroon.
}

Received: October 21, 2019; Published: November 14, 2019

DOI: $10.31080 /$ ASMI.2019.02.0438

\begin{abstract}
Groundwater pollution is a major issue because aquifers are inherently susceptible to contamination from anthropogenic impacts. Groundwater pollution takes decades or more to manifest as such it is difficult and expensive to technically remediate an aquifer once it is polluted. Douala, the most populated city in Cameroon depends heavily on its groundwater for livelihood, and only $2.16 \%$ of the 3 million inhabitants access pipe-borne water, making groundwater all the more important in this city. The study aimed at evaluating the susceptibility of groundwater in Douala to pollutants from anthropogenic sources, with specific objectives to: Identify potential anthropogenic sources of groundwater pollution in the study area; determine the quality of groundwater in the study area; and propose suitable measures to reduce anthropogenic sources of groundwater pollution. To attain the objectives, a survey was carried out to identify potential waste sources, and the sampling of 20 wells to determine the quality of the groundwater in the study area. The study identified several pollution sources amongst which were: waste dump sites, weldering workshops, auto-mechanic garages, oil sales points, septic networks, industrial and domestic effluent spots, and poor drainage construction. The results from analysis showed that, the groundwater quality of the study area ranges from good to bad in terms of both the physicochemical and biological parameters. Participatory sensitization on pollution prevention is recommended as the first step in the prevention of further pollution of groundwater from anthropogenic sources of pollution.
\end{abstract}

Keywords: Anthropogenic Pollution; Bacteriological Quality; Groundwater; Douala

\section{Introduction}

Groundwater is the most important water resource on earth [1]. About two billion people depend directly upon aquifers for drinking water, and 40 percent of the world's food is produced by irrigated agriculture that relies largely on groundwater [2]. Despite its importance, groundwater and even surface water in most communities are given very little attention in terms sanitation there by exposing them to various contamination sources. There are therefore some significant sources of diffuse and point pollution of groundwater from land use activities, particularly agricultural practices. The intrusion of these pollutants into groundwater alters the water quality and reduces its consumer value [3]. Prevention of contamination is therefore critical for effective groundwater management. Spatial variability and data constraints preclude monitoring all groundwater and make remediation activities expensive and often impractical.

Shallow aquifers with poor and doubtful water quality are major sources of water supply for drinking and other domestic purposes in many urban cities in developing countries, especially in the sub-urban areas [4-8]. These aquifers are viable complementary solution to water supply problems in urban areas, and equally because these aquifers are exposed to many sources of anthropogenic pollution, there is an obvious need for adequate protection and sustainable management [9], the best way of which still remains treatment at source. The socioeconomics development of a region depends on the availability of good quality water [10].

Douala, being an economic capital in Cameroon, is densely populated and harbors a wide range of industries ranging from food processing to chemical facilities. This city has faced a rapid growth in population, intensive urban and industrial development which has not been matched by the provision of basic sanitation (drainage, waste disposal, pipe-borne water) [9]. Inadequate supply of pipe-borne water with only sixty-five thousand persons connected out of three million inhabitants [11], pushes the increasing population to depend on groundwater. The city is also characterized by shallow water table. This puts groundwater under intense anthropogenic pressure and high risk of contamination that could lead to water borne diseases. The diverse anthropogenic activities 
in the city together with the shallow aquifer nature can cause severe degradation on both the quality and quantity of groundwater resources [12-15]. Studies have shown that water-related diseases account for about two-thirds of all recorded diseases in Cameroon and are responsible for about $50 \%$ of the reported cases of death. Many health problems faced by African countries are water-related namely; typhoid, diarrhea, cholera, dysentery [16]. According to WHO Regional Officer for Africa 2012 diarrhea remains the leading cause of infant mortality in Sub-Saharan Africa, where more than one child dies every minute. Given that about $80 \%$ of the population of the city of Douala depends directly on shallow groundwater with very doubtful water quality, it is thus very important to carry out some studies that could reveal especially the bacteriological quality of groundwater in that area. It is equally important to establish ways to avoid pollution or to reduce the pollution routes and/or educate the population on the effects of their activities on the water bodies which in turn impacts their own health. Therefore, carrying out studies on how aquifers in Douala are susceptible to anthropogenic pollution will serve as a blueprint to the sustainable management of this natural resource.

The main aim of this study therefore was to evaluate the susceptibility of the groundwater in Douala to contaminants from anthropogenic sources of pollution with specific objectives:

- To identify potential anthropogenic sources of groundwater pollution in the study area

- To determine the bacteriological quality of groundwater in the study area

- To propose suitable measures to reduce anthropogenic sources of groundwater pollution.

\section{Materials and Methods}

Description of study area

Douala, the economic capital of Cameroon is found in the Littoral Region. It is a coastal low-lying urban city which hosts more than eighty percent of industries in the country and the largest urban population in Cameroon, approx. 2 million inhabitants (1,931,977, BUCREP, 3eme RGPH, 2005). Douala has a hyper humid equatorial climate (Cameroonian type) modified by the relief of Mt Cameroon and has two seasons, a lengthy rainy season (April to October) and a dry season (November to March) [9,17]. Rainfall varies from 78.0 to $1215 \mathrm{~mm} /$ month and peak rainfall occurs within the months of June and September with an average annual precipitation of 4000 mm per annum. Temperature ranges between $23^{\circ} \mathrm{C}$ to $33^{\circ} \mathrm{C}$ with January and February identified as the hottest months of the year [9]. The relative humidity throughout the year is almost $100 \%$ (Din et al., 2008).

The Wouri and Dibamba Rivers, with their tributaries, constitute the drainage system in the entire Douala municipality [18]. They flow all year round, with the Wouri flowing within the Akwa,
Bonaberi and Bassa regions, while the Dibamba flows in the eastern outskirt of the town. Intermittent streams that are usually loaded with waste from the industries empty into these rivers [18]. Douala is almost a plain with elevations between $0-50 \mathrm{~m}$ above sea level rarely exceeding $80 \mathrm{~m}$. Flooding is frequent and severe, with severe erosive effects especially around the areas with more or less plane topography [18]. The study area is located between longitude 09038'0" and 09048'0" $\mathrm{E}$ and latitude 004000'00" and $004006^{\prime} 58^{\prime \prime} \mathrm{N}$ and covers a total area of approximately $168 \mathrm{~km} 2$ of Douala (Figure 1). The study was carried out in ten neighborhoods in the city of Douala namely; Bonamoussadi, Bali, Bonapriso, Airport, Ndogbong, Bepanda, Vallee Besengue, New Bell, Bonassama and Rail.

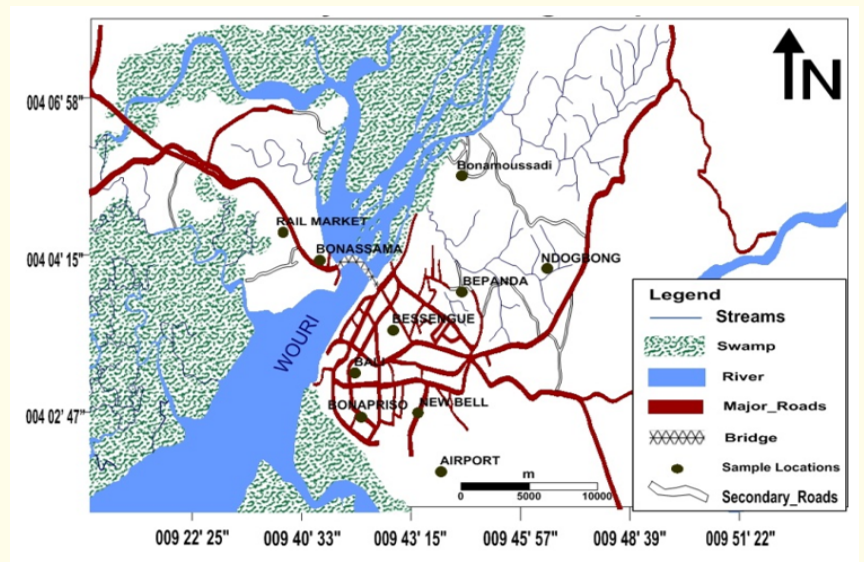

Figure 1: Location and accessibility map of the study area.

\section{Geology/hydrogeology}

The study area is part of the Douala Sedimentary Basin which is one of the coastal basins that were formed from the opening up of the South Atlantic Ocean during the break up of Gondwanaland [19]. In this coastal basin, deposits are divided into coastal sand, vases black mangrove and river alluvium. It is separated from the Rio del Rey by horst axis volcanic of Mount Cameroon-Bioko.

It is the largest coastal sedimentary basin of Cameroon, with an area of about $7000 \mathrm{~km} 2$ and a maximum width of $60 \mathrm{~km}$. It is located along the Gulf of Guinea between $3^{\circ} 00^{\prime}$ and $4^{\circ} 30^{\prime}$ North latitude and between $9^{\circ} 20^{\prime}$ and $10^{\circ} 20^{\prime}$ East longitude [9,19-21]. Douala basin is mainly made up of sandstone, limestone, siltstone and shale $[9,20]$. Unlike fractured and volcanic rock aquifers which make use of their fractures to store and release groundwater, the Douala basin is made up of rocks which are porous enough to store and release its water.

The hydrography of the Douala sedimentary basin is such that springs flow into streams which in turn flow into minor rivers like the Tongo Bassa and Ngoua, that feed the Wouri and Dibamba Rivers. They eventually empty into the Atlantic Ocean (Olivry, 1984). 
The aquifer system is mainly recharged by direct vertical infiltration of rainfall from April to September and lateral river bed infiltration throughout the year but less in the dry months as rivers reduce in volume. Additionally, the deep gullies cut by some of the rivers are deeper than the shallow water table and as such groundwater, especially in the dry season, could rather be discharging into the rivers. The study area is mainly made up of an unconfined aquifer, with water levels almost reaching the top of the wells under study. According to Nolan., et al. [22], such unconfined aquifers are closer to the land surface and are thus potential sources of contamination from sources like fertilizers and septic systems.

\section{Water sampling/onsite physico-chemical measurements}

The sampling involved the collection of 20 water samples, the onsite measurement of physico-chemical parameters (EC, TDS, temperature, $\mathrm{pH}$ ) and some interviews to the people on the water conditions, waste disposal, hygiene and major activities of their respective communities using an interview guide. The $\mathrm{pH}$, temperature, electrical conductivity (EC) and total dissolved solids (TDS) were measured using the Hanna multi parameter type. At each sampling point, the well was purged with a bucket before removing water. After measuring the physico-chemical parameters, some of the water was collected, poured into a 1litre plastic bottle which had been thoroughly rinsed with distilled water. The bottle was again rinsed with the water to be sampled to avoid any contamination. Then the bottle was filled to the brim making sure that there were no air bubbles present. The samples were stored in an ice box and transported to the Microbiological Laboratory of the University of Buea within 24 hours for analyses to prevent further growth of new organism and preserve those present.

\section{Determination of bacteriological quality (The} presumptive test)

The bacteriological analyses (total coliform count) of 20 water samples were carried out using the presumptive test. The Presumptive Test method was used to determine if gas-producing lactose fermenting-bacteria were present in a water sample. In addition to determining the presence or absence of coliform, the test can be used to determine the most probable number (MPN) of coliform count present per $100 \mathrm{ml}$ of water [23]. The setup test was made based on the fact that the water samples were relatively clear and not turbid. Lactose broth was used as the culture media, prepared in accordance with the manufacturer's instructions. The materials used were three Durham tubes of Double Strength Lactose Broth (DSLB), six Durham tubes of Single Strength Lactose Broth (SSLB) (a total of 9 tubes per sample), and twenty new syringes.

Three test tubes each containing $10 \mathrm{ml}$ DSLB, 3 test tubes containing $1.0 \mathrm{ml}$ SSLB and another set containing $0.1 \mathrm{ml} \mathrm{SSLB}$ were set up for each sample. An inverted Durham tube was put in all the test tubes of each sample. The inverted tubes were used to collect gas if present. All tubes containing the media and inverted Durham tubes were inoculated with heat to kill germs or foreign particles around the mouth and corked with clean cotton. All tubes were sterilized in an autoclave at $100 \mathrm{o} \mathrm{C}$ for an hour. The tubes were then allowed to cool. The three set tubes ( 3 each) were then labelled with a permanent marker according to the amount of water that is to be dispensed into it: $10 \mathrm{ml}, 1.0 \mathrm{ml}$ and $0.1 \mathrm{ml}$ respectively. Each water sample was shaken vigorously in order to mix the contents, opened at close range to a Bunsen burner flame to prevent influx of air bacteria and using a $10 \mathrm{ml}$ pipette, $10 \mathrm{ml}$ of water was transferred to each of the DSLB tubes; with a $1.0 \mathrm{ml}$ pipette, $1 \mathrm{ml}$ of water was transferred to each of the middle set of tubes (3); and $0.1 \mathrm{ml}$ to each of the last three SSLB tubes. Each tube was corked with cotton wool after being inoculated with the right dose of water. This was done for all the 20 samples.

The set up was incubated for 24 hours at $35 \mathrm{o} \mathrm{C}$ and the inverted Durham tubes were examined for the presence of gas. The absence of gas in all lactose broth tubes indicates the absence of coliforms and water is safe to drink. If gas is present only after 48 hours, the gas is probably not due to coliforms but if $10 \%$ or more gas is present in one or more tubes in 24 hours, water is presumed to be unsafe to drink. The MPN was determined by referring to Table VI Appendix (A) in Benson [23] and results obtained. The quality of the water was deduced by determining the bacteriological content in the water samples, and comparing the results with World Health Organisation (WHO) [24] bacteriological standard for drinking water.

\section{Results and Interpretation \\ Potential pollution sources}

Some of the major potential pollution sources that were identified are; Dump sites (waste sorting sites and Cameroon Hygiene and Sanitation company (HYSACAM) spots), weldering workshops, auto mechanic garages (painting, cars and moto bikes), open dumps, oil sale points, septic pipes in to drainage pattern, industries (sewage and effluents in to rivers), fridge repair shops and poor drainage systems. Figure 2 shows some potential pollution sources and their closeness to some wells.

\section{Physical parameters}

The values of the parameters that were measured insitu in the field are as shown on table 1.

\section{Bacteriological analysis and suitability of water for drinking}

Groundwater is used extensively as a source of potable water since in some areas, surface supplies are insufficient, unavailable or require extensive purification and treatment [25]. The total coli- 


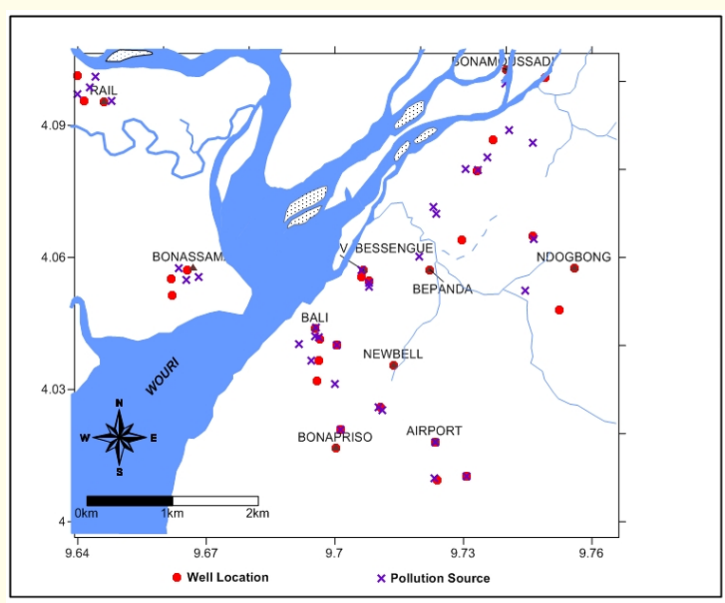

Figure 2: Map showing points of some major potential pollution sources and some wells. Note the closeness of most pollution sources to wells.

form bacterium (e.g. E. coli) was used to assess the bacteriological quality of water. The very presence of coliform in any water sample irrespective of the count is an indication of contamination of the water source and suggests that there may be disease-causing agents in the water. The count determines the extent of contamination. The results of the bacteriological analysis are shown in table 2 and 3.

\section{Discussion of Results}

Potential pollution sources

Most of the pollution sources identified were closer to the wells, thereby putting the ground water under high risk of vulnerability to pollution. The potential pollution sources identified are summarized on the table 4 with their suspected pollutants and figure 3 shows pictures of some potential pollution sources.

Water quality

Physical parameters

The $\mathrm{pH}$ value ranges from 3.7 to 6.9 with an average value of 5.32 (Table 2 above). As such the ground water in the area can be interpreted as acidic in nature. This could be related to the abundance of $\mathrm{HCO}_{3}$ - ions in the groundwater which might dissolve releasing hydrogen ions which increases the acidity of the water [2630]. The water temperature of the sampled wells range between 26.2 and $28.6^{\circ} \mathrm{C}$ with an average value of $27.72^{\circ} \mathrm{C}$ (Table 2) and was more or less similar in the different areas. These similar values and small standard deviation value (0.695701) suggest a single aquifer in the area of study. High EC values (such as 834 and $1240 \mu \mathrm{S} / \mathrm{cm}$ ) could be as a result of high incorporation of the dissolved components of the bedrock (from intense weathering) and a high influence from anthropogenic activities.

\begin{tabular}{|l|c|c|c|c|}
\hline \multicolumn{1}{|c|}{ Sample code } & pH & Temp ${ }^{\mathbf{C}}$ & EC $(\boldsymbol{\mu S} / \mathbf{c m})$ & TDS $(\boldsymbol{\mu S} / \mathbf{c m})$ \\
\hline Bonamoussadi 1 (BS1) & 6.1 & 26.2 & 345 & 220.8 \\
\hline Bonamoussadi 2 (BS2) & 5.8 & 28.3 & 665 & 445.6 \\
\hline Bali 1 (BA1) & 4.7 & 27.7 & 349 & 223.36 \\
\hline Bali 2 (BA2) & 4.7 & 27.8 & 407 & 272.7 \\
\hline Bonapriso 1 (BP1) & 3.7 & 28.6 & 207 & 132.48 \\
\hline Bonapriso 2 (BP2) & 4.7 & 28.1 & 222 & 148.7 \\
\hline Airport 1 (AP1) & 4.8 & 28.4 & 345 & 220.8 \\
\hline Airport 2 (AP2) & 4.2 & 28 & 324 & 217.1 \\
\hline Ndogbong 1 (ND1) & 4.6 & 27.4 & 403 & 257.92 \\
\hline Ndogbong 2 (ND2) & 5.9 & 27.6 & 284 & 190.3 \\
\hline Bepanda 1 (BE1) & 4.4 & 27.6 & 354 & 226.56 \\
\hline Bepanda 2 (BE2) & 4.9 & 27.5 & 221 & 148.1 \\
\hline Vallee Besengue 1 (VB1) & 5.9 & 28 & 444 & 284.16 \\
\hline Vallee Besengue 2 (VB2) & 6.0 & 28.3 & 355 & 237.9 \\
\hline New Bell 1 (NB1) & 6.8 & 27.5 & 834 & 533.76 \\
\hline New Bell 2 (NB2) & 6.9 & 27.8 & 1240 & 830.8 \\
\hline Bonassama 1 (BM1) & 6.7 & 27.4 & 283 & 181.12 \\
\hline Bonassama 2 (BM2) & 6.8 & 28.3 & 744 & 498.5 \\
\hline Rail 1 (RA1) & 5.5 & 28.4 & 635 & 406.4 \\
\hline Rail 2 (RA2) & 5.3 & 28.3 & 345 & 231.2 \\
\hline Mean & 5.32 & 27.72 & 419.9 & 268.736 \\
\hline Stdev & 1.039017 & 0.695701 & 183.5668 & 117.4827 \\
\hline
\end{tabular}

Table 1: Physical parameters. 


\begin{tabular}{|l|c|c|c|}
\hline \multicolumn{1}{|c|}{ Location } & MPN Index per 100ml & Category & Quality Type \\
\hline Bonamoussadi 1 (BS1) & $>1,100$ & D & Grossly polluted \\
\hline Bonamoussadi 2 (BS2) & $>1,100$ & D & Grossly polluted \\
\hline Airport 1 (AP1) & $>1,100$ & D & Grossly polluted \\
\hline Airport 2 (AP2) & 240 & D & Grossly polluted \\
\hline Ndogbong 1 (ND1) & $<3$ & B & Acceptable \\
\hline Ndogbong 2 (ND2) & $>1100$ & D & Grossly polluted \\
\hline Bepanda 1 (BE1) & 4 & C & Unacceptable \\
\hline Bepanda 2 (BE2) & 1100 & D & Grossly polluted \\
\hline Bali 1BA1 & 15 & C & Unacceptable \\
\hline Bali 2 (BA2) & 1100 & D & Grossly polluted \\
\hline Bonapriso 1 (BP1) & $>1,100$ & D & Grossly polluted \\
\hline Bonapriso 2 (BP2) & 1100 & D & Grossly polluted \\
\hline Vallee Besengue 1 (VB1) & $>1,100$ & D & Grossly polluted \\
\hline Vallee Besengue 2 (VB2) & 28 & C & Unacceptable \\
\hline New Bell 1 (NB1) & 39 & C & Unacceptable \\
\hline New Bell 2 (NB2) & $>1100$ & D & Grossly polluted \\
\hline Bonassama 1(BM1) & $>1,100$ & D & Grossly polluted \\
\hline Bonassama 2 (BM2) & 210 & D & Grossly polluted \\
\hline Rail 1 (RA1) & 43 & B & Unacceptable \\
\hline Rail 2 (RA2) & $<3$ & Acceptable \\
\hline
\end{tabular}

Table 2: Results of Bacteriological Analysis (Chessbrough, 2002).

Note: From table, water samples BS1, BS2, AP1, AP2, ND2, BE2, BA2, BP1, BP2, VB1, NB2, BM1 and BM2 were grossly polluted with coliform bacteria; BE1, BA1, VB2, NB1 and RA1 were unacceptable while ND1 and RA2 were acceptable for consumption.

\begin{tabular}{|l|c|c|c|}
\hline S/N & Classification & $\begin{array}{c}\text { MPN/100ml } \\
\text { Coliform Bacteria }\end{array}$ & Summary for Study area \\
\hline 1. & Bacteria quality applicable to disinfection treatment only & $0-50$ & ND1, BE1, BA1, NB1, VB2, RA1, RA2 \\
\hline 2. & $\begin{array}{c}\text { Bacteria quality requiring conventional methods of treatment } \\
\text { (coagulation, filtration, and disinfection) }\end{array}$ & $50-5,000$ & $\begin{array}{c}\text { BS1, BS2, AP1 AP2, ND2, BE2, BA2, BP1, } \\
\text { BP2, VB1, NB2, BM1, BM2 }\end{array}$ \\
\hline 3. & Heavy pollution requiring extensive type of treatment & $5000-50,000$ & Not Applicable (N/A) \\
\hline 4. & $\begin{array}{c}\text { Very heavy pollution, unacceptable unless special treatments } \\
\text { designed for such water is used }\end{array}$ & Above 50, 000 & N/A \\
\hline
\end{tabular}

Table 3: Bacteriological analysis for Study area compared with WHO (2004) Bacteriological Standard for Drinking water.

\begin{tabular}{|l|c|}
\hline \multicolumn{1}{|c|}{ Potential Pollution Sources } & Suspected Pollutants \\
\hline $\begin{array}{l}\text { Dump sites (waste sorting sites and } \\
\text { HYSACAM spots) }\end{array}$ & $\begin{array}{c}\text { leachate, hazardous pollutants (from Batteries), heavy metals (mercury, lead), } \\
\text { organics }\end{array}$ \\
\hline Weldering workshops & oil, metallic particles, paints \\
\hline Garages (painting, cars and moto bikes) & Lubricants, hydrocarbons, paints, grease \\
\hline Open dumps & leachate, hazardous pollutants (from Batteries), heavy metals (mercury, lead) \\
\hline Oil sale points & Sewage (effluent and sludge) \\
\hline Septic pipes in to drainage pattern & Industrial effluents (e.g Guinness) \\
\hline Industries (waste in to rivers) & CFC, oil \\
\hline Fridge repair shops & Effluent, sewage, sludge \\
\hline Poor drainage construction & \\
\hline
\end{tabular}

Table 4: Potential pollution sources and suspected pollutants. 


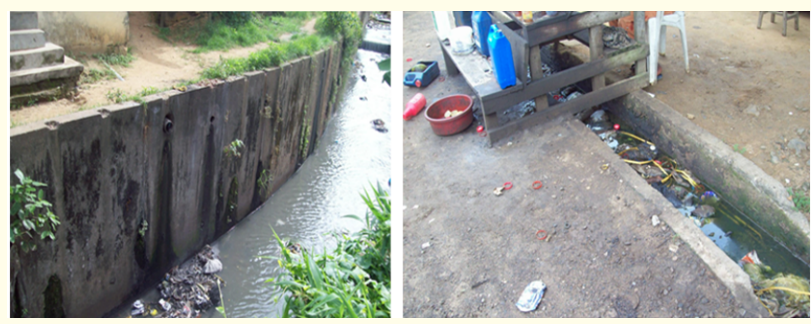

Figure 3a: Main Drainage Conduit at Bali. (Note pipe with household waste draining in to conduit).

Figure 3b: Oil sales point in New Bell. (Note oil film in the drain).

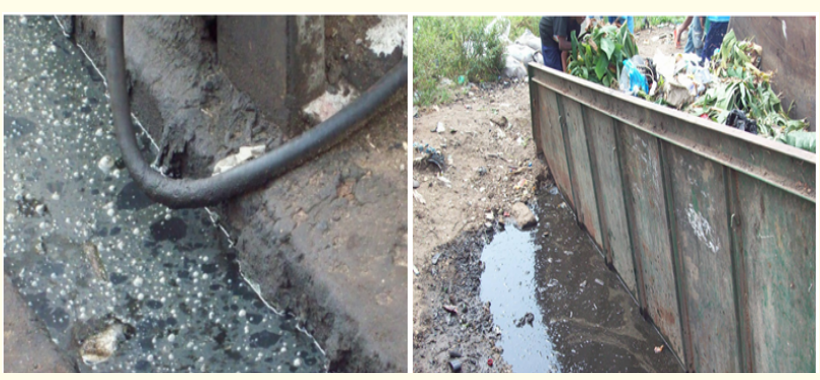

Figure 3c: Oil spills from a garage at Bali. (Note oil film in the drain)

Figure 3d: A Dump site at New Bell (Note leachate underneath the bin).

Figure 3: Pictures of some potential pollution sources.

\section{Microbial analysis}

Bacteriological test carried on the groundwater samples detected the presence of total coliform in all water samples except water sample ND1 (Ndogbong) and RA2 (Rail). The presence of Coliform bacteria in the water samples is an indication of contamination from an anthropogenic source of pollution. This could be attributed to the poorly constructed toilets, septic tanks and poor drainage systems in the study area. Previous studies showed that in shallow aquifers, such as those in the study area, percolating water from surface sources can provide sufficient nutrients to support microbial growth; an unusually high bacterial population could indicate infiltration of contaminated water into the aquifer [25].

\section{Conclusions and Recommendations}

Douala is a city where groundwater plays an important role in water supply. The aquifer in this city is under great pressure from a variety of sources such as urbanization, over abstraction and industries. It is also characterized by several sources of pollution which could affect groundwater which include; weldering workshops, auto mechanic garages, open dumps, poorly constructed toilets, oil sale points, septic pipes in to drainage pattern and poor drainage construction.
The results from analysis showed that, the groundwater quality of the study area ranges from good to bad in terms of physicochemical parameters. Furthermore, the results of the bacteriological analysis of groundwater show that about $80 \%$ of the city's inhabited area is contaminated. As such, the ground water is therefore not potable water. However, in order to avoid further groundwater contamination from anthropogenic source of pollution, the entire population needs to be sensitized on the effect of their activities on the groundwater of the area.

From results obtained, the following recommendations were made:

- $\quad$ Aquifer protection measures should be implemented such as the restriction of the construction of septic systems and toilets that empty in to drains.

- The general public should be sensitized on the importance of groundwater and the effects of their activities on this valuable resource.

- Environmental Impact Assessment and risk assessment should precede all land use and industrial development, to ensure protection of harm or mitigation of perturbance on groundwater.

- Monitoring programs should be set up because the aquifer is under risk of pollution by contaminants from the surface.

\section{Acknowledgements}

Our acknowledgements go to the reviewers, whose comments helped improve on this article.

\section{Bibliography}

1. Mohammad N. "Assessment of intrinsic vulnerability to contamination for Gaza coastal aquifer, Palestine". Journal of Environmental Management 88 (2008): 577-593.

2. Morris BL., et al. "Groundwater and its Susceptibility to Degradation: A Global Assessment of the Problem and Options for Management. Early Warning and Assessment Report Series, RS. 03-3. United Nations Environment Programme, Nairobi, Kenya (2003).

3. Melloul A and Collin M. "Water quality factor identification by the Principal ComponentsT statistical method". Water Science Technology 34 (1994): 41-50.

4. Howard S., et al. "Childhood resilience: review and critique of literature'”. Oxford Review of Education 25.3 (1999): 307-323.

5. Pedley S and Howard G. "The public health implications of microbiological contamination of groundwater". Quarterly Journal of Engineering Geology 30 (1997): 179-188. 
6. Tanawa E., et al. "Habitat and protection of water resources in suburban areas in African cities". Building and Environment 37.3 (2002): 269-275.

7. Zingoni, E., et al. "Effect of semi-formal urban settlement on groundwater quality Epworth (Zimbabwe): Case study and groundwater quality zoning". Physics and Chemistry of the Earth 30 (2005): 680-688.

8. Kulakabo NR., et al. "Study of the impact of land-use and hydrogeologic setting on shallow groundwater quality in a periurban area of Kampala, Uganda". Science Total Environment 381 (2007): 180-199.

9. Eneke G., et al. "Controls on groundwater chemistry in a highly urbanised coastal area". International Journal of Environment Restricted 5.2 (2011): 475-490.

10. Voudouris, K., et al. "Assessment of intrinsic Vulnerability using DRASTIC model and GIS in the Kiti Aquifer, Cyprus". Europeaan water 30 (2010): 13-24.

11. Guévart E., et al. "Déterminats du cholera á Douala". Medecin Tropical 66 (2006): 283-291.

12. UNESCO. "Summary and recommendations of the international conference on world water resources at the beginning of the 21st century. "water: a loomimng crisis" Paris, France (1998).

13. Civita M. "Le carte della vulnerabilita degli acquiferi allT inquinamento (in Italian)". In: Pitagora, editor. Teoria and Practica, Bologna (1994): 325.

14. Polemio M. "Seawater intrusion and groundwater in the Southern Italy region of Apulia: a multi-methodological approach to the protection". UNESCO IHP 77 (2005): 171-178.

15. Polemio M., et al. "Monitoring and methods to analyse the ground water quality degradation risk in coastal Karstic aquifers (Apulia, Southern Italy)". Environ-Geolog 58.2 (2008): 299-312.

16. Katte V., et al. "Domestic water quality in urban centers in Cameroon: a case of study of dschang in the West Province". Africa water Journal (2003): 43-54.

17. Ndjama J., et al. "Water supply, sanitation and health risks in Douala, Cameroon". African Journal of Environmental Science and Technology 2.12 (2008): 422-429.

18. Fonge B., et al. "Fish (Arius heudelotii Valenciennes, 1840) as bio-indicator of heavy metals in Douala Estuary of Cameroon". African Journal of Biotechnology 10.73 (2011): 16581-16588.
19. Asaah VA., et al. "Heavy metal concentration and distribution in surface soils of the Bassa Industrial Zone 1 Douala Cameroon". The Arabian Journal for Science and Engineering 31.2A (2006): 147- 158.

20. Tamfu S and Batupe M. "Geologic Setting, Stratigraphy and Hydrocarbon Habitat of the Douala Basin Cameroon". National Hydrocarbon Journal of Cameroon 3 (1995): 6.

21. Feumba R., et al. "Relationship between Climate and Groundwater Recharge in the Besseke Watershed (Douala-Cameroon)". Journal of Water Resource and Protection 3 (2011): 607619.

22. Nolan BN., et al. "A National Look at Nitrate Contamination of Ground Water". Water Conditioning and Purification 39.12 (1988): 76-79.

23. Benson HJ. "Microbiological Applications". Laboratory Manual in General Microbiology; 8th Edition; Mc. Graw Hill Companies, New York (2002): 478.

24. WHO. Guidelines for Drinking-Water Quality; 3rd Edition; Geneva, Switzerland (2004): 514.

25. Allen MJ and Geldreich EE. "Bacteriological criteria of Groundwater Quality". Groundwater 13 (1975): 45-52.

26. World Health Organization WHO. "Guidelines for drinking-water quality - 4th ed”. WHO Library Cataloguing-in-Publication Data (2011).

27. Alemayehu T. "The impact of uncontrolled waste disposal on surface water quality in Addis Ababa, Ethopia”. SINET Ethiopian Journal 24.1 (2001): 93-104.

28. Cheesbrough M. "District Laboratory Practice in Tropical Countries Part 2". Butterworth (2002): 143-154.

29. Djuikom E., et al. "Assessment of the quality of water in wells at Bépanda quarter, Douala-Cameroon, by use of the indicator bacteria of faecal contamination". Journal of Applied Biosciences 37 (2011): 2434 -2440.

30. WHO. "Water Quality: Guidelines, Standards and Health; Edited by Lorna Fetrwell and Jamie Bartram; IWA Publishing; London, UK, ISBN: 190022228 (2001): 424.

Volume 2 Issue 12 December 2019 (C) All rights are reserved by Akenji Victorine Neh and Tarkang Carine Enow. 